\title{
Value Engineering Study of Various Gantry Girder Profile
}

\author{
S. Dutta, D. Chatterjee
}

\begin{abstract}
The present work envisages a comparative study between various gantry girder profiles. The design is performed considering both strength and serviceability criteria as per IS 800:2007. The analysis for dead load and live load are done as per IS: 875 -1987 (Part-I) and IS: 875 -1987 (Part-II) respectively. The different combinations of profile geometry that are chosen includes 'I'-section with top and bottom plates, symmetrical plate girder section, 'I'-section with ' $\mathrm{C}$ '-section as top flange, plate girder with top flange as rolled ' $\mathrm{C}$ '-section and unsymmetrical plate girder section. The problems are formulated taking in to consideration of practical demands of industries. Gantry girders are analyzed for gantry spans of $5 \mathrm{~m}, 7 \mathrm{~m}, 9 \mathrm{~m}$ and $12 \mathrm{~m}$ each with crane capacity of $100 \mathrm{kN}, 200 \mathrm{kN}$ and $300 \mathrm{kN}$ respectively. An attempt is made to identify the most optimum combinations of sections for each category of crane capacity and gantry span. Finally, to aid designers, handouts in the form of graphs, charts and tables are furnished which can be used to identify the best possible option of gantry profile considered in the present study. Other than these guidelines are also provided to find the most economical section for combinations of spans and crane capacities that are not presented in detail in this paper.
\end{abstract}

Index Terms - Biaxial bending, gantry girder, section profile, economical.

\section{Nomenclature:}

Abbreviations and symbols mentioned below shall have their following meaning, unless or otherwise specified.

$\begin{array}{ll}\text { Abbreviations } \\ \text { BM } & \text { Bending moment }(\mathrm{kN}-\mathrm{m}) \text {. } \\ \mathrm{SF} & \text { Shear force }(\mathrm{kN}) \text {. } \\ \mathrm{I}+\mathrm{P} & \text { 'I'-section with top and bottom plates. } \\ \mathrm{SPG} & \text { Symmetrical plate girder section. } \\ \mathrm{I}+\mathrm{C} & \text { 'I'-section with 'C'-section as top flange. } \\ \mathrm{PL}+\mathrm{C} & \text { Plate girder with only rolled 'C'-section as top } \\ & \text { flange. } \\ \text { UPG } & \text { Unsymmetrical plate girder section. }\end{array}$
Subham Dutta, Department of Civil Engineering, Heritage Institute of Technology, Kolkata, India.

Dona Chatterjee, Assistant Professor Department of Civil Engineering, Heritage Institute of Technology, Kolkata, India.

\author{
Symbols \\ $M_{d} \quad$ Design bending moment $(\mathrm{kN}-\mathrm{m})$. \\ $V_{c r} \quad$ Shear force corresponding to web buckling \\ $(\mathrm{KN})$. \\ $F_{c d w} \quad$ Buckling strength of unstiffened web. \\ $F_{w} \quad$ Local design capacity of web in bearing.
}

\section{INTRODUCTION}

Gantry cranes have major priority in heavy industries, manufacturing plants, shipping docks and railway yards where transportation of excessive weights occurs routinely. Gantry girder is the segment which transfers the loads from the crane to the vertical load bearing members.

Gantry girders are designed in a very conservative approach for the maximum factored vertical and lateral bending moment and share forces. So the capacity of the section can be increased by optimization of the gantry profile and at the same time, the requirement of steel can also be reduced.

In this paper, analysis and design of gantry girder is performed by using different gantry profiles which are represented in Fig.1.

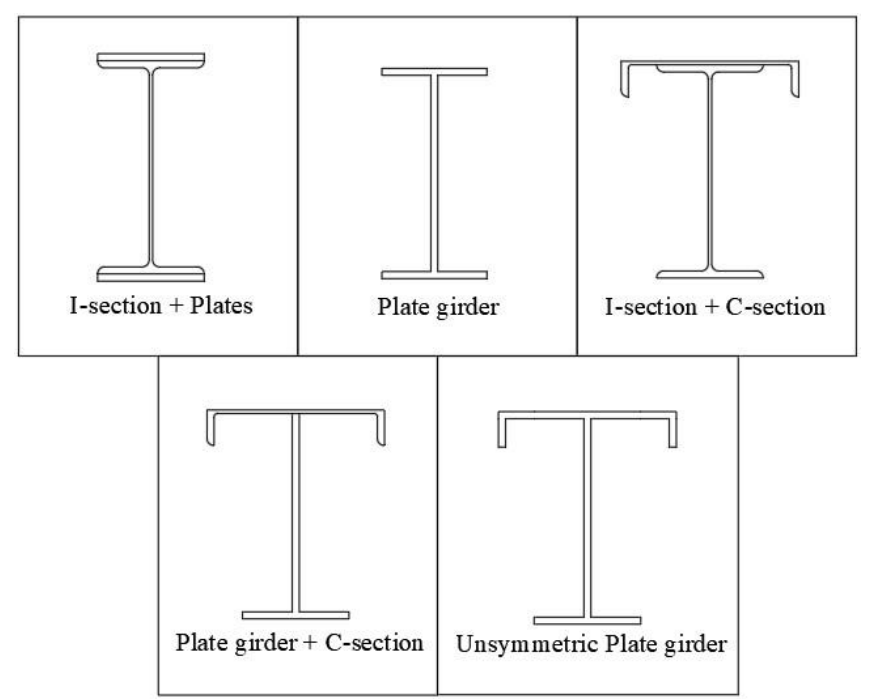

Fig.1. Schematic diagram of different types of gantry profiles

\section{Problem Definition}

The problems which are authors' own are presented and solved in this section. Crane capacity of $100 \mathrm{kN}, 200 \mathrm{kN}, 300$ $\mathrm{kN}$ and gantry spans of $5 \mathrm{~m}, 7 \mathrm{~m}, 9 \mathrm{~m}$ and $12 \mathrm{~m}$ are considered 
for this study. The various other specifications that are taken as constant for all the cases are mentioned in Table I.

Table I: Design parameters

\begin{tabular}{ll}
\hline $\begin{array}{l}\text { Self-weight of crane girder excluding } \\
\text { trolley }\end{array}$ & $200 \mathrm{kN}$ \\
$\begin{array}{l}\text { Self-weight of trolley, electric motor, } \\
\text { hook etc. }\end{array}$ & $50 \mathrm{kN}$ \\
Minimum hook approach & $1.2 \mathrm{~m}$ \\
Wheel base distance & $3.5 \mathrm{~m}$ \\
Span of crane girder & $20 \mathrm{~m}$ \\
Self-weight of rail section & $0.3 \mathrm{kN} / \mathrm{m}$ \\
Self-weight of gantry girder section & $1.6 \mathrm{kN} / \mathrm{m}$ \\
Diameter of crane wheel & $150 \mathrm{~mm}$ \\
Grade of steel used & $\mathrm{E} 250$ \\
\hline \hline
\end{tabular}

\section{Design procedure:}

\section{Step1: Calculation of maximum wheel load}

- For calculating maximum wheel load the hook of the trolley should be at a distance of minimum hook approach from the end of the crane girder.

- Due to impact loading $25 \%$ extra load should be considered (as per IS 875(2):1987 clause 6.3) [7].

- A load factor of 1.5 should be multiplied with the obtained value [6].

\section{Step2: Calculation of surge load}

- Total lateral surge load should be considered as $10 \%$ of the crane load plus trolley load.

- A load factor of 1.5 should be multiplied with the obtained value.

\section{Step3: Calculation of longitudinal breaking load}

- Longitudinal breaking load should be calculated as 5\% of the static wheel load.

- A load factor of 1.5 should be multiplied with the obtained value.

\section{Step4: Calculation of bending moment}

- Bending moment due to wheel load should be calculated using absolute maximum bending moment theorem.

- Bending moment produced by self-weight of gantry girder and rail section and bending moment due to longitudinal breaking load should be considered.

- Summation of all these bending moments is the total bending moment generated in the gantry girder. A load factor of 1.5 should be multiplied with the obtained bending moment to find out the factored bending moment.

- Bending moment due to lateral surge load should take into consideration which acts in the horizontal direction.

Step5: Calculation of shear force

- Maximum shear force due to wheel load can be obtained when one set of crane wheel is placed just at the support.
- Shear force due to self-weight of gantry girder and rail section and reaction due to drag should be considered.

- Summation of these entire shear forces is the total shear force generated in the gantry girder. A load factor of 1.5 should be multiplied with the obtained shear force to find out the factored shear force.

\section{Step6: Assumption of section}

- The assumed depth of the gantry girder section should be within the economic depth and the shear depth.

- Area of flanges should be calculated from the bending moment criteria. As the gantry girder has to withstand bi-axial bending so the assumed area of flanges should be increased by $30-40 \%$.

\section{Step7: Check for bending moment capacity of the section}

- Vertical and lateral bending moment capacities of the provided section should be calculated as per IS 800:2007 clause 8.2.2. [5].

- If the interaction ratio for bi-axial bending is less than one then the section is safe against bending.

Step8: Check for share force capacity of the section

- Shear force corresponding to web buckling $\mathrm{Vcr}$ is calculated as per clause 8.4.2.2 of IS 800:2007 [5].

- If the calculated share force capacity of the section is greater than the factored share force then the section is safe against share.

\section{Step9: Check for web buckling}

- Buckling strength of unstiffened web Fcdw can be calculated as per clause 8.7.3.1 of IS 800:2007 [1] [5].

\section{Step10: Check for web crippling}

- Local design capacity of web in bearing Fw can be calculated as per clause 8.7.4 of IS 800:2007 [5].

\section{Step 11: Check for deflection}

- Lateral and horizontal deflection of gantry girder under service loads should be less than (gantry span/750) in $\mathrm{mm}$ [4].

\section{RESUlts AND DisCUSSION}

The generated factored vertical bending moments $\left(\mathrm{M}_{\mathrm{ZZ}}\right)$, lateral bending moments $\left(\mathrm{M}_{\mathrm{YY}}\right)$ and factored shear forces (SF) of different gantry spans are tabulated in Table 2. These entities are load dependent entities and remain constant for all types of gantry profiles.

Table II: Developed bending moments and shear forces for different combinations of gantry span and crane capacities

\begin{tabular}{|l|l|l|l|l|}
\hline $\begin{array}{l}\text { Gantry } \\
\text { span }\end{array}$ & $\begin{array}{l}\text { Crane } \\
\text { capacity }\end{array}$ & $\begin{array}{l}\text { Mzz } \\
(\mathbf{k N}-m)\end{array}$ & $\begin{array}{l}\text { Myy } \\
(\mathbf{k N}-\mathbf{m})\end{array}$ & $\begin{array}{l}\text { SF } \\
(\mathbf{k N})\end{array}$ \\
\hline \multirow{3}{*}{$5 \mathrm{~m}$} & $100 \mathrm{kN}$ & 249.76 & 5.94 & 302.2 \\
\cline { 2 - 5 } & $200 \mathrm{kN}$ & 343.7 & 9.9 & 417.29 \\
\cline { 2 - 5 } & $300 \mathrm{kN}$ & 437.64 & 13.86 & 532.38 \\
\hline \multirow{3}{*}{$7 \mathrm{~m}$} & $100 \mathrm{kN}$ & 464.81 & 11.07 & 349.85 \\
\cline { 2 - 5 } & $200 \mathrm{kN}$ & 639.3 & 18.46 & 482.42 \\
\cline { 2 - 5 } & $300 \mathrm{kN}$ & 813.79 & 25.84 & 614.98 \\
\hline
\end{tabular}


Available online at www.ijrat.org

\begin{tabular}{|l|l|l|l|l|}
\hline \multirow{4}{*}{$9 \mathrm{~m}$} & $100 \mathrm{kN}$ & 691.36 & 16.43 & 377.59 \\
\cline { 2 - 5 } & $200 \mathrm{kN}$ & 949.76 & 27.38 & 519.86 \\
\cline { 2 - 5 } & $300 \mathrm{kN}$ & 1208.2 & 38.33 & 662.14 \\
\hline
\end{tabular}

The section properties of the various combinations of profile sections and bending moment and shear force capacities are tabulated in Table 3 to Table 5. Sections properties which include vertical bending moment capacity (MZZ), lateral bending moment capacity (MYY), shear force capacity (SF),

\begin{tabular}{|l|l|l|l|l|}
\hline \multirow{3}{*}{$12 \mathrm{~m}$} & $100 \mathrm{kN}$ & 1043.26 & 24.62 & 403.64 \\
\cline { 2 - 5 } & $200 \mathrm{kN}$ & 1430.17 & 41.04 & 554.41 \\
\cline { 2 - 5 } & $300 \mathrm{kN}$ & 1817.07 & 57.46 & 705.18 \\
\hline
\end{tabular}

cross sectional area $(\mathrm{C} / \mathrm{S})$ and weight per meter length of the given sections are tabulated for different gantry spans and gantry profiles. Fig 2 to Fig 4 shows the graphical representation of weight of steel required per meter length different gantry profiles.

Table III: Sectional properties and load carrying capacities of different profile geometry for crane capacity of $100 \mathrm{KN}$

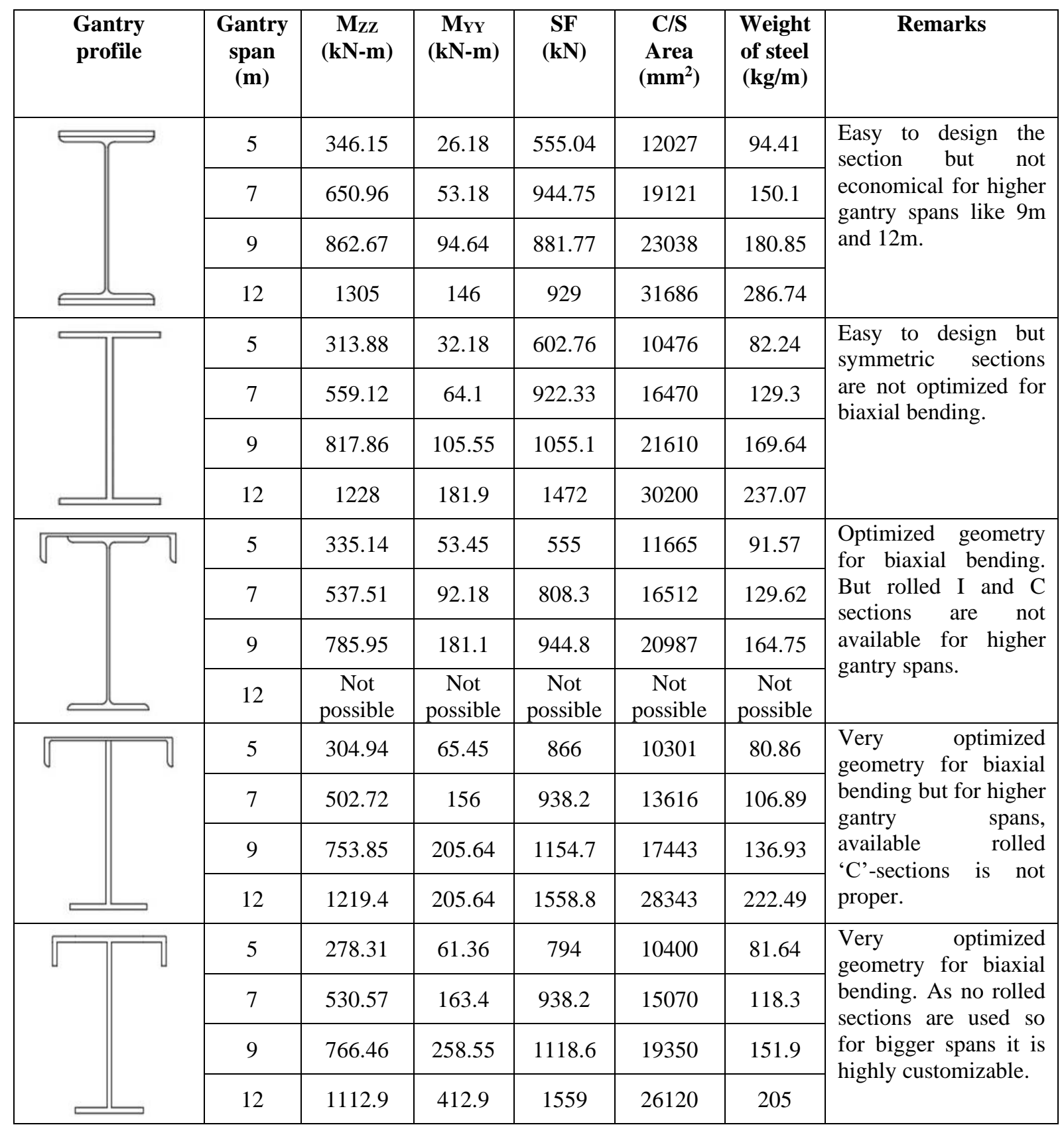

From Table 3 clearly indicates for low crane capacity like $100 \mathrm{kN}$ and for gantry spans $5 \mathrm{~m}, 7 \mathrm{~m}$ and $9 \mathrm{~m}$ the most economic gantry profile is "Plate girder with only rolled
'C'-section as top flange" but for gantry span of $12 \mathrm{~m}$ "Unsymmetrical plate girder section" is the most economic profile. 
International Journal of Research in Advent Technology, Vol.8, No.6, June 2019

E-ISSN: 2321-9637

Available online at www.ijrat.org

Table IV: Sectional properties and load carrying capacities of different profile geometry for crane capacity of 200KN

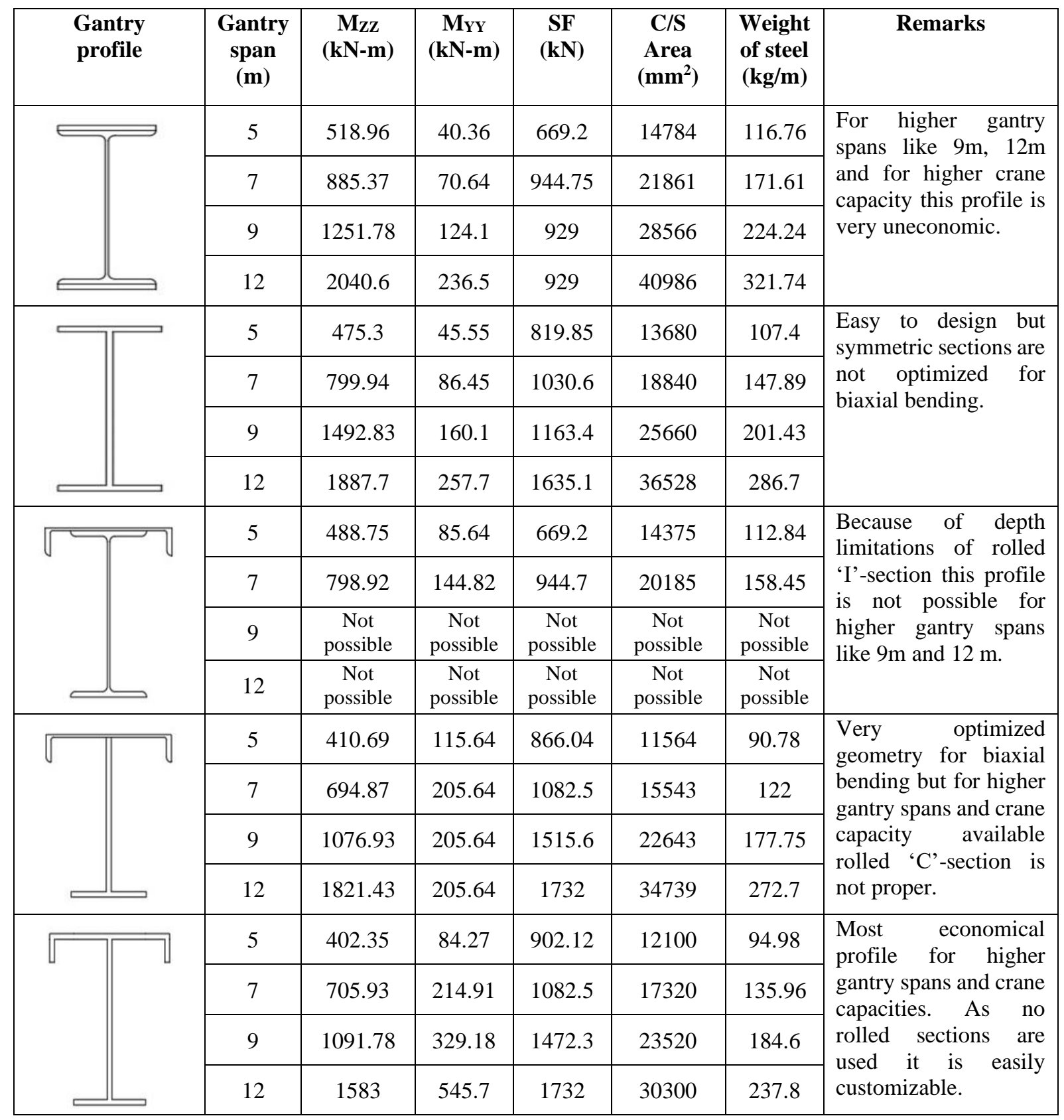

From Table 4 clearly indicates for medium crane capacity like $200 \mathrm{kN}$ and for gantry spans $5 \mathrm{~m}, 7 \mathrm{~m}$ and $9 \mathrm{~m}$ the most economic gantry profile is "Plate girder with only rolled
'C'-section as top flange" but for gantry span $12 \mathrm{~m}$ "Unsymmetrical plate girder section" is the most economic profile.

Table V: Sectional properties and load carrying capacities of different profile geometry for crane capacity of 300KN

\begin{tabular}{|c|c|c|c|c|c|c|c|}
\hline $\begin{array}{l}\text { Gantry } \\
\text { Profile }\end{array}$ & $\begin{array}{c}\text { Gantry } \\
\text { Span } \\
\text { (m) }\end{array}$ & $\begin{array}{c}\mathbf{M z z}_{\mathrm{zz}} \\
(\mathbf{k N}-\mathbf{m})\end{array}$ & $\begin{array}{c}\text { MYY }_{\mathbf{Y}} \\
(\mathrm{kN}-\mathrm{m})\end{array}$ & $\begin{array}{c}\text { SF } \\
(\mathbf{k N})\end{array}$ & $\begin{array}{c}\text { C/A } \\
\text { Area } \\
\left(\mathrm{mm}^{2}\right)\end{array}$ & $\begin{array}{l}\text { Weight } \\
\text { of steel } \\
(\mathrm{kg} / \mathrm{m})\end{array}$ & Remarks \\
\hline \multirow[t]{3}{*}{ 戸 } & 5 & 649.15 & 48 & 808.29 & 17011 & 133.54 & \multirow{4}{*}{$\begin{array}{l}\text { Depth limitation of } \\
\text { rolled 'I'-section make } \\
\text { this profile } \\
\text { uneconomical for } \\
\text { higher gantry spans } \\
\text { and crane capacities. }\end{array}$} \\
\hline & 7 & 1103.38 & 99.55 & 881.71 & 24238 & 190.26 & \\
\hline & 9 & 1678.5 & 170.45 & 929 & 33886 & 266 & \\
\hline$\Longleftarrow$ & 12 & 2748.6 & 359.5 & 929 & 49986 & 392.4 & \\
\hline
\end{tabular}


International Journal of Research in Advent Technology, Vol.8, No.6, June 2019

E-ISSN: 2321-9637

Available online at www.ijrat.org

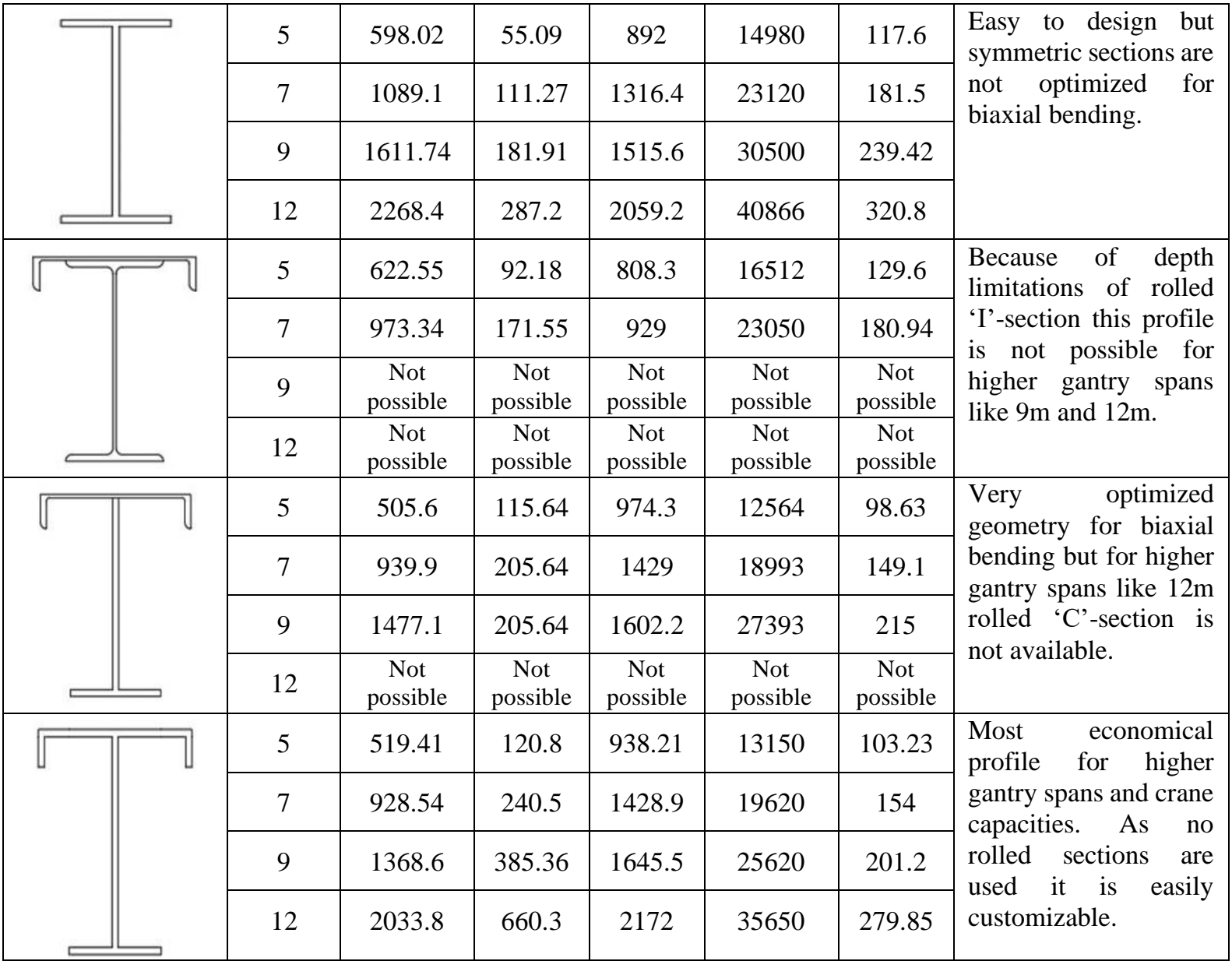

From Table 5 clearly indicates for high crane capacity like $300 \mathrm{kN}$ and for gantry spans $5 \mathrm{~m}$ and $7 \mathrm{~m}$ the most economic gantry profile is "Plate girder with only rolled ' $\mathrm{C}$ '-section as top flange" but for gantry span 9m and $12 \mathrm{~m}$ "Unsymmetrical plate girder section" is the most economic profile.

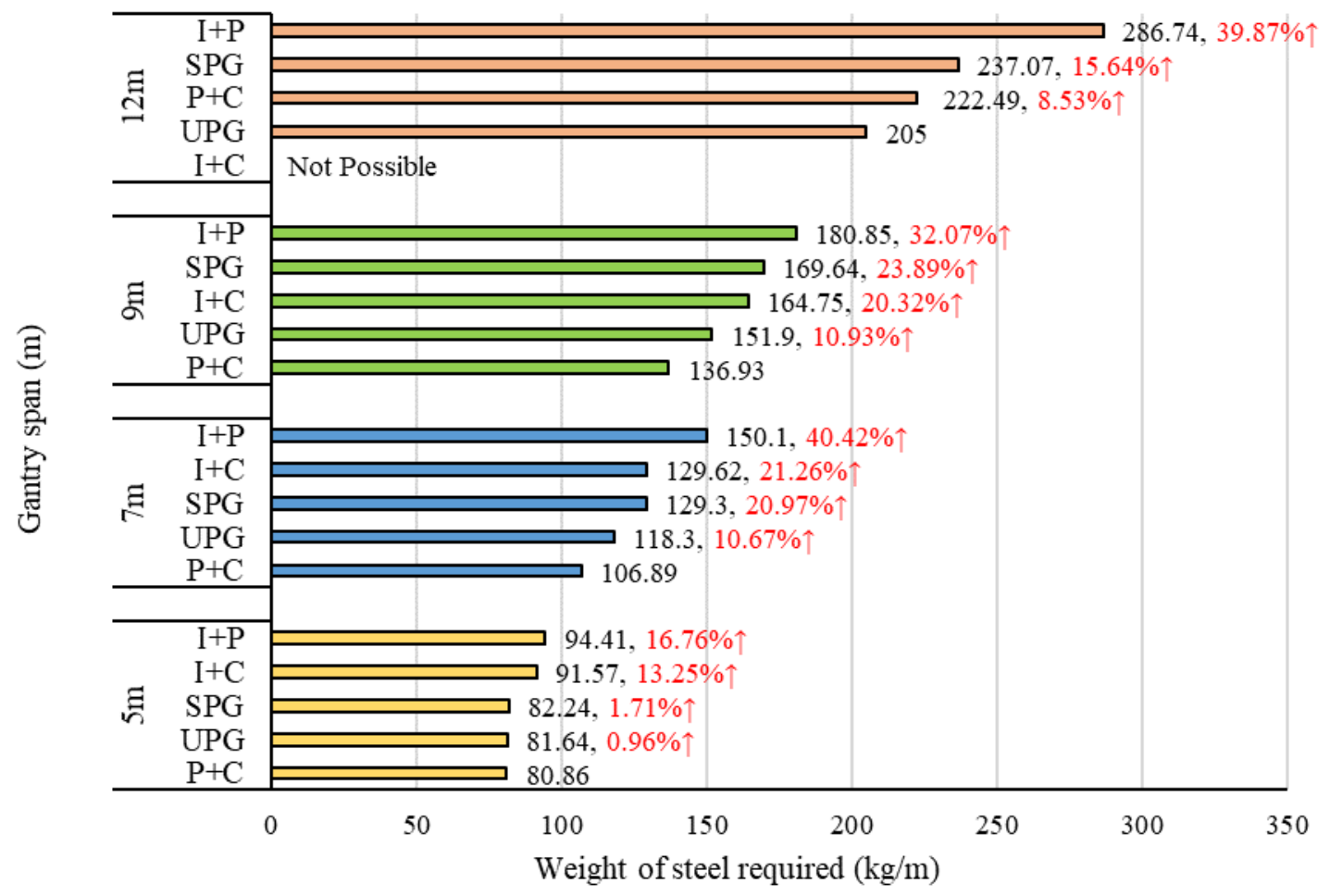

Fig.2. Steel requirements of different gantry profiles for crane capacity $100 \mathrm{kN}$ 


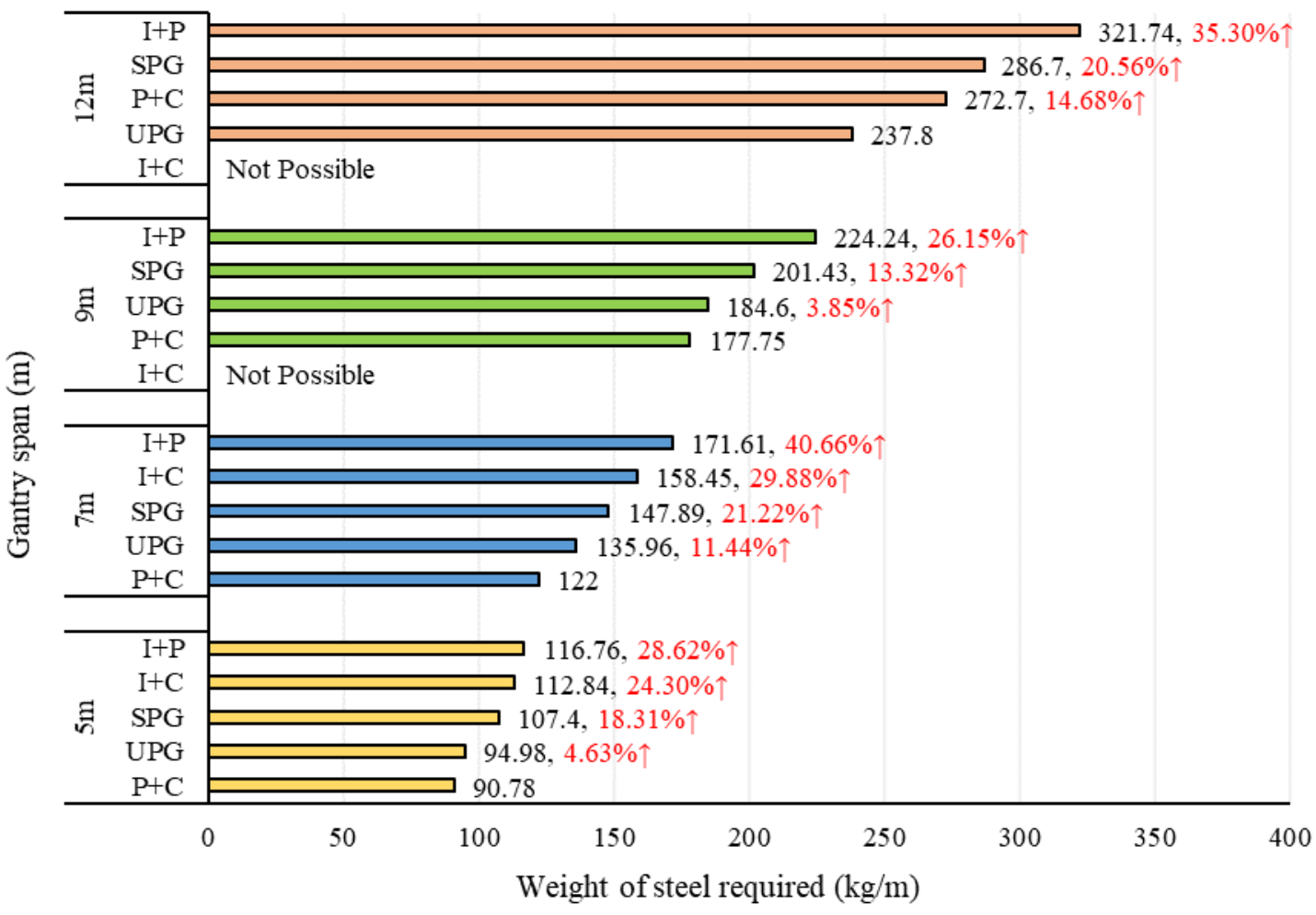

Fig.3. Steel requirement of different gantry profiles for crane capacity $200 \mathrm{kN}$

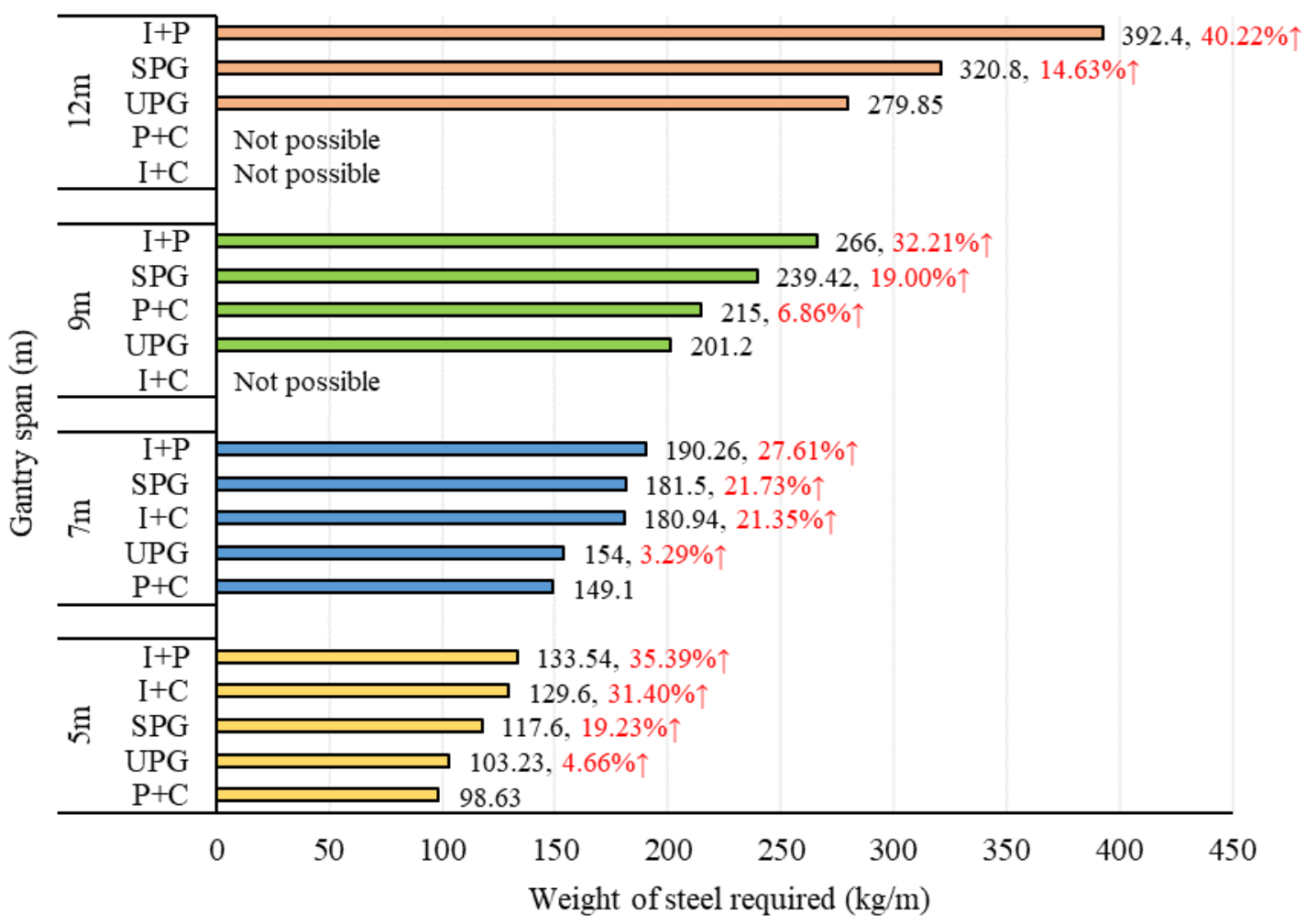

Fig.4. Steel requirement of different gantry profiles for crane capacity $400 \mathrm{kN}$

*The blank bar represents that the gantry profile is not possible for that particular gantry span because of the unavailability of the rolled section.

Figure 4-6 depicts the weight of steel required per meter length of gantry girders of various gantry profiles for crane capacities of $100 \mathrm{kN}, 200 \mathrm{kN}$ and $300 \mathrm{kN}$ respectively. The percentage of extra steel required for different gantry profiles with respect to the most economic gantry profile for a particular gantry span are also indicated. 


\section{Design Methodology}

The design is initiated with a very basic symmetrical sections like "rolled I-section with top and bottom plates" and "symmetrical plate girder section" [2] [3]. But the problem with the first gantry profile is the depth of the rolled section is limited so for higher gantry spans and crane capacities the available profile becomes very uneconomical.

For gantry girders as the horizontal surge load is transferred at the top flange level (specifically at the contact point of crane wheel and gantry rail) so using unsymmetrical section with bigger compression flange is found to be more economical. So in the subsequent trial the gantry profiles are

\section{Conclusions}

- Load calculations for gantry girders are done in a very conservative way so by optimizing the gantry girder profile economy can be achieved.

- Gantry girders are such kind of steel beams where vertical and lateral bending moments can come at a

\section{CONFLICT OF INTEREST}

On behalf of all authors, the corresponding author states that there is no conflict of interest.

\section{REFERENCES}

[1] Alandkar,P.M. and Limaye,A. 2013. Strength of Welded Plate Girder with Corrugated Web Plate. Journal of Engineering Research and Applications, 3(5): 1925-1930.

[2] Garg,A. 2016. Gantry girders in India. International Journal of Civil, Mechanical and Energy Science, 2(6): 15-19.

[3] Iyappan,S. Kumar,P.V. Sarathy,R.V. Tamilvanan,G. Venkatesh,A. and Vignesh,S. 2016. Design of an overhead plate gantry girder.International Journal of Development Research, 6(5): 7821-7823.

[4] Subramanian,N. 2010. Steel Structures Design and Practice, Oxford University Press, New Delhi.

[5] IS 800:2007, Code of practice for general construction in steel, Bureau of Indian Standards, New Delhi.

[6] IS 875(part I):2003, Code of practice for design loads (other than earthquake) for buildings and structures, Bureau of Indian Standards, New Delhi.

[7] IS 875(part II):2010, Code of practice for design loads (other than earthquake) for buildings and structures, Bureau of Indian Standards, New Delhi.

\section{AUTHORS PROFILE}

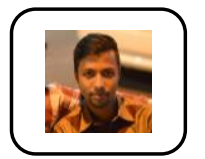

Subham Dutta is pursuing his B.Tech degree in Civil Engineering from Heritage Institute of Technology, Kolkata.

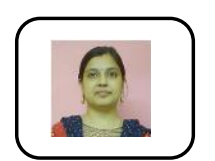

Dona Chatterjee received B.E. and M.E. degrees in Civil Engineering and Structural Engineering from Jadavpur University, Kolkata in the year 2010 and 2015 , respectively. Author has 3 years of industrial experience and 6 years of academic and research experience mainly in areas of structural engineering. considered as "rolled I-section with rolled C-section as top flange" and "web and bottom flange as plate section with top flange as rolled C-section". As a result the sections are found to be very economical but the problem is the rolled sections are not available for the higher gantry spans and crane capacities.

To eliminate this problem in the third and final trial keeping the same geometry as per second trial the whole gantry profile is designed as plate girder section with bigger compression flange as $\mathrm{C}$-section. This results into the most economic section for gantry span of $9 \mathrm{~m}$ and $12 \mathrm{~m}$. same time. So the designed sections need to be safe against bi-axial bending.

- For gantry girders horizontal loads are released at the top flange level so unsymmetrical sections (with a bigger compression flange) will be more economical than symmetrical sections. 